\title{
A második esély problematikája az oktatási rendszerben
}

\section{The problem of second chance in the Hungarian education system}

\author{
BAJUSZ KLÁRA
}

Bajusz Klára: Pécsi Tudományegyetem, Bölcsészettudományi Kar, Humán Fejlesztési és Müvelődéstudományi Intézet, Felnőttképzési és Képességfejlesztési Tanszék; bajusz.klara@pte.hu

Klára Bajusz: University of Pécs, Faculty of Humanities, Institute for Human Development and Cultural Studies, Department of Adult Education and Human Development; bajusz.klara@pte.hu

\begin{abstract}
Absztrakt
A tanulmány a második esély lehetőségeinek megjelenését vizsgálja a hazai közoktatás és felsőoktatás rendszerében. Kitér a korai iskolaelhagyás hazai helyzetére, valamint azokra a változásokra, melyek az iskolarendszerü felnőttoktatásban az utóbbi évtizedekben történtek. A szerző elemzi a felnőttkorban szerzett végzettségek egyenértéküségének kérdéseit is. A tanulmány leszögezi: ha a töredékvégzettségüek számára nem biztosítunk második esélyt, marginalizálódásuk elkerülhetetlen.
\end{abstract}

Kulcsszavak: második esély, közoktatás, felsőoktatás, iskolarendszerü felnőttoktatás

\begin{abstract}
This paper reviews second chance opportunities in the education system of Hungary. It revises early school leaving data, changes in second chance schools in recent decades, and the questions of equivalence of the qualifications achieved in adulthood. If early school leavers do not receive a second chance their marginalisation is inevitable.
\end{abstract}

Keywords: second chance, education system, higher education, adult learning

\section{A második esély}

A tankötelezettség 19. századi megjelenése óta az iskolába járás általános jelenség. Ha körülnézünk saját, középosztálybeli környezetünkben, azt hihetjük, hogy a dolgok nagyjából rendben mennek: gyerekeink időben befejezik tanulmányaikat, a tananyag nem motiváló ugyan, de osztályzataik is nagyrészt az elvárásainknak megfelelőek, az iskolával tulajdonképpen kevés konfliktusunk adódik.

Ha azonban kicsit szélesebb körben tekintünk ki, könnyen észrevehetjük azokat a jelenségeket, melyek életre hívják a második esélyt: mi történik azokkal, akik a társadalom „fősodrába” nem illeszkednek, hátrányokkal érkeznek ebbe a fünyíróelvü, poroszutas iskolarendszerbe, és sokszor külső okok miatt lesznek kudarcos tanulók, melynek eredményeképpen idő előtt otthagyják az iskolát.

A lemorzsolódás jelensége az iskola intézményével egyidős. Ez nagyrészt három, egymással összefüggő tényezőből következik: a társadalmi esélyegyenlőtlenségből, az 
iskolarendszer müködési hibáiból, valamint az iskola szelekciós jellegéből. Akár belső, akár külső ok vezet a lemorzsolódáshoz, a töredékvégzettséggel való iskolaelhagyás hátrányt generál. Ennek ellenére nem mindenki számára adott a lehetőség arra, hogy rendeskorban, azaz első esélyben, a „királyi úton” fejezze be tanulmányait. Milyen megoldás adatik azok számára, akik nem tudtak, vagy nem akartak élni az első esély adta lehetőségekkel? Miért kell egyáltalán biztosítanunk a második esélyt mindazoknak, akik „saját hibájukból” nem jutottak eléggé elöre az iskolarendszerben?

A tanuláshoz való jog mindenkit megillet, melynek egyik alapfeltétele az esélyegyenlőség biztosítása. Senkit ne érhessen hátrány azért, mert későn érett meg benne a tanulás iránti vágy. A hozzáférés megvalósítása társadalmi-gazdasági igényként is artikulálódik, hiszen a folyamatos fejlődés egyik kulcsa a közösség tagjainak képezhetősége.

A felnőttkori tanulás mindig saját döntés eredménye - akkor is, ha külső motiváció (pl. munkaerőpiaci kényszer) hatására jön létre -, illetve addig tart, míg a tanulási motiváció fenntartható. Az iskolapadba kényszerrel visszaültetni felnőttkorban senkit sem lehet.

Minél képzetlenebb egy felnőtt, annál nehezebben kezd újra tanulni. A korábbi rossz iskolai tapasztalatok, a sok tanulás nélkül töltött év, a gyenge alapkészségek és tanulási képességek ijesztővé teszik az újrakezdést. A tudás értékét fel nem ismerő környezet számára is idegen, ha egy képzetlen felnőtt tanulásra adja a fejét - magyarázkodni, a gúnyos megjegyzéseket türni pedig nagyon nehéz akkor, ha valaki még a saját döntésének helyességében sem biztos. Természetesen ennek ellenkezője is igaz. Ha valaki rendszeresen fogad be új ismereteket, korábbi tanulási tapasztalatai pozitívak, önbizalom és sikerélmény hajtja, környezete számára is elfogadott az önfejlesztés igénye, akkor a tanulás az élet természetes részévé válik (Zrinszky, 1996).

Mivel a felnőttkori tanulás önkéntes, motivációfüggő, és áldozatokat igényel pénzben, energiában és időben, kiemelten értékes jelenség kell, hogy legyen a társadalom számára. Így a felnőttoktató számára is. Azt, ha valaki felnőttként tanul - és kiemelten akkor, ha iskolázatlan -, minden esetben tiszteletben kell tartanunk! Itt pedig feltétlenül ki kell térnünk a felnőttoktató szerepére annak ellenére, hogy (vagy éppen azért, mert) erkölcsi felelősségéről ritkán beszélünk. Pedig nagyon sok múlik azon, hogy a felnőttoktató hogyan viszonyul a tanuló felnőtthöz, milyen módszereket alkalmaz, milyen a foglalkozás hangulata, mennyire tudja a tanulási motivációt életben tartani, elfeledtetni a korábbi tanulási kudarcokat. Ha a felnőttoktató rosszul dolgozik, a lemorzsolódás megnő. Minél iskolázatlanabb a felnőtt, annál érzékenyebben reagál a tanári hibákra. Így a felnőttoktató felelősséget kell, hogy érezzen azért, ami munkája eredményeképp születik. Ha egy képzetlen felnőtt - legyőzve bizonytalanságát és félelmét vállalkozik a tanulásra, majd újra kudarcot vall, és lemorzsolódik, valószínüleg többé nem vehető rá arra, hogy iskolapadba üljön. Ez pedig a társadalom egészét érintő következményekkel jár.

Társadalmi szintű következményekkel jár a képzetlenség is, így az iskolarendszerü felnőttoktatás intézményrendszerének fenntartása közösségi érdek (pótló funkció, kompetenciát biztosító funkció). Hiszen az iskolázatlanság funkcionális analfabetizmust, életviteli hátrányokat, rosszabb egészségi állapotot és munkanélküliséget szül - ráadásul mindez jellemzően továbböröklődik a következő generáció(k)ra. A foglalkoztathatóság javítása egész Európában kiemelt oktatáspolitikai cél; ennek egyik eszköze pedig a versenyképes tudással nem rendelkező munkaképes korúak arányának csökkentése, ami a hiányzó alapkészségek megteremtése nélkül nehezen elképzelhető. 


\section{Korai iskolaelhagyás}

A második esély kérdéskörének kifejtéséhez számos olyan fogalmat használunk, melyek definíciója messze nem egységes. Ilyen az esélyegyenlőség, a lemorzsolódás, a korai iskolaelhagyás, sőt, maga a második esély fogalma is.

A korai iskolaelhagyás (early school leaving) fogalmát az Európai Unió is használja. Definíciója a következő: korai iskolaelhagyók azok a 18-24 évesek, akik legfeljebb alsó középfokú végzettséggel rendelkeznek, és oktatásban, képzésben nem részesülnek ${ }^{1}$ (Council of Europe, 2003: 2). A korai iskolaelhagyók aránya nagy szóródást mutat az Unión belül: 2018ban a horvátoknál 3,3\%, míg 17,9\% a spanyoloknál. Az uniós átlag 2008-ban még 14,9\% volt, tíz évvel később 10,6\%. A magyar ráta 2002 és 2008 között fél százalékkal, 11,7\%-ra mérséklődött, 2018-ban újra 12,5\% (Eurostat, n.d.*). Az Európa 2020 célkitüzése az, hogy a korai iskolaelhagyók aránya ne haladja meg a 10\%-ot.

A másik, nemzetközi viszonylatban alkalmazott méröszám a NEET (nem tanuló, nem dolgozó) fiatalok társadalmi aránya (Eurostat, n.d.**). Ez a jelenség is szorosan összefügg számos más tényező mellett - a korai iskolaelhagyással, hisz a munkaeröpiacról nagy eséllyel kimaradó fiatalok gyakran halmozott hátrányokat hoznak: instabil család, munkanélküli szülők, kistelepülésen élés, szegénység, iskolázatlanság. A NEET fiatalok aránya nemzetközi átlagban $15 \%$ körüli értéket mutat; ezzel a magyar ráta gyakorlatilag megegyezik (OECD, 2019).

A korai iskolaelhagyás és a lemorzsolódás fogalma nyilván összefügg. Az első azonban a rendeskorúakra vonatkozó indikátor, a lemorzsolódás viszont tágabb fogalom. Lemorzsolódónak tekintjük azt, aki az iskolarendszerben vagy azon kívül, életkortól és iskolatípustól függetlenül, formális vagy nonformális tanulás során anélkül hagyja félbe tanulmányait, hogy a kimenetig eljutna. A fogalom kissé másképp is értelmezhető, amennyiben a jelenséget az iskolarendszerben vizsgáljuk: itt az iskola félbehagyása mellett a következő oktatási szintre való továbblépés elmaradása is lemorzsolódást jelenthet.

A közoktatásban lemorzsolódással veszélyeztetett tanulók támogatásához kapcsolódó korai jelző- és pedagógiai támogató rendszer 2017-től Magyarországon is - mint minden uniós tagállamban - müködik.

\section{Az iskolarendszerü felnőttoktatás változásai}

A második esélyt azonban nem biztos, hogy mindenki igénybe is tudja venni azok közül, akikben a tanulás igénye megfogalmazódik. Az utóbbi évtizedekben az oktatásban erösödtek a települési szegregációs folyamatok (Varga, 2018), mely az esélyegyenlőtlenség veszélyét növeli: a tanuláshoz való hozzáférés lehetősége a társadalom egyes csoportjai között erősen megoszlik. Ezeket a társadalmi különbségeket az iskolarendszer nemigen tudja (nem is mindig akarja) áthidalni, növelve a tanuláshoz való hozzáférés hiányának továbbörökítéséböl is adódó társadalmi kettészakadást.

Az iskolarendszerben - mind az első, mind a második esély tekintetében -, mivel az intézmények nincsenek felkészülve arra, hogy a gyors munkaerőpiaci változásokat a szakképzési kínálat folyamatos változtatásával kövessék, megnőtt a „,zsákutcás” szakképzések aránya. A szakmunkások magasabb munkanélküliségi rátája, kisebb állásbiztonsága, a fizikai munka jellege bizonytalanná teszik az itt végzők jövőképét (Balázs, Kocsis \&Vágó, 2011). A fiatal felnőttek körében nő az iskolarendszerben, illetve iskolarendszeren kívül továbbtanulók

\footnotetext{
${ }^{1}$ A definíciót az EU oktatási miniszterei határozták meg 2003 májusában.
} 
aránya azok között is, akik befejezett szakmai végzettséggel lépnek ki az iskolarendszerből, de a megszerzett képesítéssel nem tudnak elhelyezkedni. Természetesen nem mindenkiben élnek olyan erős tanulási motivációk, melyek arra késztetnek, hogy egy sikeresen megszerzett, de „eladhatatlan” végzettség birtokában visszaüljenek az iskolapadba: sokan elvesztik az oktatási rendszerbe vetett bizalmunkat, könnyen tartós munkanélkülivé, inaktívvá válnak, vagy a feketegazdaságban próbálnak megélhetést keresni.

A fiatalok számának csökkenése az iskolákban a normatív támogatás mértékének biztosítására egyfajta „tanulómegtartó” magatartást alakít ki, melynek következtében csökkenhet az oktatás színvonala (pl. kevesebb buktatás), illetve egyes képzési formákban vagy tanulócsoportokban túlzottan megnőhet azoknak a túlkoros tanulóknak a száma, akiket korábban a felnőttek iskolái „,vettek át” és próbáltak végzettséghez, illetve szakképesítéshez juttatni.

Mivel az egész életen át tartó tanulás a középosztálybeli munkavállalók számára is megkerülhetetlen, a felnőttképzés különböző célcsoportjai jelentős piaci tényezőként jelennek meg azáltal, hogy tanulási folyamatukat gyakran saját maguk kénytelenek finanszírozni. Az így kialakuló fizetőképes kereslet pedig alakítja a piaci alapon müködő felnőttképzési kínálatot.

Az esélyegyenlőség továbbra is valós tartalom nélküli eszme: az ismeretek értékké transzformálása a tudásgazdaságban csak azok számára megoldható, akik rendelkeznek versenyképes kompetenciákkal és tudással. Ezek megszerzésének lehetősége pedig a fejlett gazdaságokban sem mindenki számára egyenlő feltételekkel adott - anyagi, szociális és földrajzi aspektusból sem. A leszakadó és marginalizálódó rétegek előnytelen társadalmi és gazdasági pozícióikat, gyakran halmozottan hátrányos helyzetüket továbbörökíthetik utódaikra (pl. harmadik/negyedik generációs munkanélküliek). Ök pedig már megfelelő minták híján nem tudnak, de nem is akarnak szocializálódni abban a társadalomban, melyben státuszuk eleve determinált.

\section{Második esély az oktatás különböző szintjein}

\section{Közoktatás}

Az iskolázottsági ráta folyamatos növekedésével az alapfokú iskolai felnőttoktatás Magyarországon mára gyakorlatilag megszünt (2300-2400 tanuló évente országos szinten). Ez azért rejt magában komoly veszélyeket, mert a töredékvégzettséggel rendelkezők hazai aránya még mindig 5-10\% között van, és újratermelödik.

Középfokon, esti vagy levelező munkarendben 85 ezer fö tanult a tavalyi tanévben (KSH, 2018). Az érettségi második esélyben való megszerzése sokak számára motiváló erő a mai napig: a középfokú iskolai végzettségnek van munkaerőpiaci értéke, a továbbtanulás alapját jelenti, valamint segít stabilizálni az érintettek munkaeröpiaci státuszát. A középfokon tanulók szociális helyzete is stabilabb, alapkészségeik és tanulási képességeik jobbak. A közoktatásban második esélyben tanuló felnőttek lemorzsolódási adataival szórványosan rendelkezünk, ezt a területet eddig kevesen vizsgálták (OFI, 2009).

\section{Felsőoktatás}

A tavalyi tanév adatai szerint a magyar felsőoktatásban levelező munkarendben 73 ezren, az esti képzéseken 3,6 ezren, míg távoktatásban 4900-an tanultak (KSH, 2018). Mondhatnánk, hogy második esélyben, de nem feltétlenül. A második esély fogalma a felsőoktatásban 
nehezebben értelmezhető, mint a közoktatásban, mivel a rendeskorúak és felnőttkorúak fogalmi határai elmosódnak.

A fogalmi tisztázást nehezíti az is, hogy a tankötelezettség megszünik, mire a hallgató felsőoktatásba kerül, így a kudarcok okainak vizsgálata is más súlyú, mint a közoktatásban. A közoktatásban 22 év a nappali munkarendü képzésekbe való bekapcsolódás felső életkori határa, azaz ennél idősebbek számára már csak részidős képzések elérhetőek. A szakképzésben ez a határ 25 év. A felsőoktatásban nincs korhatár, azaz akár 100 évesen is lehetünk nappali tagozatos hallgatók. Ebből értelemszerüen következik, hogy a részidős képzések (esti, levelező, távoktatás) sem kötöttek életkorhoz.

A munkarendek kiválasztása leginkább élethelyzettől függ: munka, kisgyermek mellett nehéz a nappali tagozat követelményeit teljesíteni, így a felnőtt, időszerkezeti sajátosságai miatt, ritkán választja ezt a munkarendet. Ebböl az is következik, hogy a felnőtt, jellemzően levelezős hallgatóként nem feltétlenül a második esélyt veszi igénybe - gyakran első diplomáját szerzi. Emellett gyakori, hogy felnőttek második-harmadik felsőfokú végzettségért tanulnak, ami viszont már nem második esélyként értelmezhető. Az is egyre gyakrabban előfordul, hogy rendeskorú hallgató levelezőn végzi el a választott szakot annak ellenére, hogy élethelyzetét, státuszát tekintve nem felnőtt: nincs munkaviszonya, nem nevel gyermeket, nem él önálló háztartásban stb.

A felsőoktatásban történő lemorzsolódás vizsgálata is elsősorban a rendeskorúakra koncentrál. Csók Cintia kutatási eredményei kiterjednek a levelező munkarendben tanulókra is, kiemelve, hogy az optimális időben végzettek aránya itt valamivel jobb, mint a nappalisoknál (52,6 és 49\%). Ennek ellenére megállapítja, hogy összességében a levelezősök lemorzsolódási rátája magasabb, mint a nappali munkarendben tanulóké, bár az okok feltárására nem vállalkozik (Csók és mtsai., 2018). Kerülő Judit (2018) a lemorzsolódási okokat akadémiai, szervezeti, szociális, környezeti, pszichológiai tényezőkre és háttérváltozókra osztja, melyek néhol természetesen különböző hangsúllyal, de - mindkét életkori csoportra jellemzőek lehetnek: ebből a felosztásból is kitünik, milyen összetett, sokszor többtényezős okok vezetnek a felsőoktatásban is a lemorzsolódáshoz. Engler Ágnes (2014) levelezős hallgatókra irányuló vizsgálatában kiemeli a család és a tanulás összehangolásának nehézségeit.

A felsőoktatásban második esélyben tanuló felnőttek jellemzői eltérnek a közoktatásban tanulókétól. Mivel eleve iskolázottabbak (legalább érettségizettek), alapkészségeik jellemzően jók, fejlettebb tanulási képességeik vannak, önérvényesítő képességük erősebb, kiterjedtebb társadalmi tőkével rendelkeznek. Motiváltabbak is, hiszen a diploma munkaerőpiaci értéke jól mérhető, érdemes energiát, időt és pénzt fektetni megszerzésébe. Sok felnőttet a tanulás öröme, a tudásvágy juttat el a felsőoktatásig, ez pedig az egyik legerősebb belső motiváció. A nappali munkarendben tanulók között sokkal több a „sodródó”: ők közép- vagy hosszútávú tervek, sokszor érdeklődés nélkül tanulnak, céljuk a túlélés, nem a valós tudásszerzés.

A felnőtt előnyt kovácsolhat még élethelyzetéből, sajátos időszerkezetéből is: munka és/vagy család mellett tanulva kénytelen idejét és energiáit hatékonyan beosztani, egyensúlyozni számos kötelezettség között. Tudatosabban, így hatékonyabban van jelen a tanulási folyamatban; végzettsége a munkáltató szemében is bizonyító erejü.

Minél idősebb a tanuló, annál több élet- és munkatapasztalattal rendelkezik. A hozott tudás megkönnyítheti az új ismeretek elsajátítását, alapot adva azoknak. A meglévő tapasztalatokra épülő tanulás sokszor revelációként megélt, amikor az új tudás a régivel összeépülve aha-élményt ad. A jobb tanulási képességek okán a tapasztalatcsere, az egymástól tanulás is hatékony, és mivel sok-sok szakmai területről és életútról érkező hallgatók kerülnek egy tanulócsoportba, felnőtteket tanítani általában az oktató számára is tanulságos élmény. 


\section{A felnőttkorban szerzett végzettségek egyenértéküsége}

A második esélyben szerzett végzettségek jogi egyenértéküsége deklarált: a rendeskorban, illetve a felnőttkorban szerzett iskolai végzettségek de jure, azaz jogilag egyenértéküek, tanügyi dokumentumaik azonos formátumúak (általános iskolai végzettség, érettségi bizonyítvány, diploma). Ha ez a garancia hiányozna, a második esély értéktelenedne el, hiszen nem lenne biztosított az esélyegyenlőség akkor, ha valaki iskolai végzettségét nem a „királyi úton”, hanem felnőttkorban szerzi meg. A jogi értelemben vett egyenértéküség egyik biztosítéka az egységes vizsgarendszer; azaz életkortól, iskolafokozattól és munkarendtől függetlenül azonosak a kimeneti elvárások (megegyeznek a vizsgatípusok, érettségi- és záróvizsga-tételsorok stb.). Vagyis nem az iskolába járás körülményei, hanem a kimeneti vizsgán nyújtott teljesítmény szüri meg, hogy ki jogosult az egyes iskolai végzettségek megszerzésére - más szavakkal felnőttként is ugyanúgy el kell érni ugyanazt a tudásszintet, amely a felnövekvő nemzedékek iskoláiban alkot standard minimumot (Csoma, 2000).

A helyzet tehát tisztának tünhet: törvény mondja ki, így minden iskolai végzettség, attól függetlenül, ki milyen életkorban vagy iskolában szerzi azt meg, ugyanannyit ér. Természetesen tudjuk, hogy mindez a mindennapokban messze nem ilyen egyértelmü - az egyenértéküséget nem elég törvényben deklarálni. Számolnunk kell ugyanis a „fogyasztók” és „megrendelők”, azaz a tanuló felnőttek és az őket támogató munkáltatók, a társadalom véleményével is. A felnőttkorban szerzett végzettségek de facto, azaz a gyakorlatban megvalósuló egyenértéküsége sokkal összetettebb kérdés a de jure egyenértéküségnél.

A második esélyben szerzett végzettségek gyakorlatban történő megítélése a mindennapok során alakul ki. Ezt a megítélést formálja egyrészt a tanuló/hallgató családjának, szükebb-tágabb közösségének álláspontja és reakciói, azaz a társadalomban kialakult közvélemény. A felnőttkori tanulás sikere részben a „hátországon” múlik. Ha a tanulni vágyó családja nem ad biztos hátteret - hiszen nem hisz a megszerzendő végzettség értékében, fölösleges munkaként, és nem befektetésként értékelve azt -, akkor a tanulás folytonos küzdelemmé, bizonyítási kényszerré válik, és könnyen lehet, hogy kudarccal, lemorzsolódással végződik.

A másik tényező, amely alakítja a de facto egyenértéküséget, a munka világa. Az iskolai végzettségek felnőttkorban történő megszerzésének szándéka mögött legtöbbször a munkaerőpiaccal kapcsolatos motivációk rejlenek. A végzettségek értékét pedig azok „eladhatósága” szabja meg, ez pedig a munkáltató reakcióin mérhető leginkább.

A de jure-de facto egyenértéküség kérdését azonban nem zárhatjuk le addig, míg az iskola szemszögéből meg nem vizsgáltuk azt. A tanárnak a felnőttoktatásban - a kontaktórák alacsony száma miatt (jellemzően nem nappali munkarend!) - kevesebb ideje marad ugyanannyi tananyag közvetítésére. Így az esti és levelező munkarend esetében a tanuló számára a siker egyik kulcsa az önirányított tanulás képessége, mely azonban önkontrollt, önállóságot és tudatosságot követel - emellett az iskolai keretek legtöbbször nem ideálisak az önirányított felnőttkori tanulás megvalósulásához (Cserné Adermann, 2000).

A második esélyben szerzett iskolai végzettségek egyenértéküségét több aspektusból is megvizsgáltuk, elemezve a tanuló felnőttek, a társadalom, valamint a munkaadók attitűdjeit az alap-, közép- és felsőfokú oktatásban egyaránt (Bajusz, 2014). A társadalomban csökkenni látszik az az elöítélet, amely a felnőttkori tanulást ,gyorstalpalónak” tekinti - a megkérdezettek kevesebb mint fele válaszolt elítélően az iskolarendszerü felnőttoktatásban tanulókról, bár a nem tanuló felnőttek jellemzően a második eséllyel kapcsolatos ismeretek nélkül nyilatkoznak negatívan az egyenértékűségről. Érdekes, hogy az előítélettel gondolkodók harmada mégis azt 
vallja, hogy a munkaerőpiacon nem számít, hogy mikor szerezte a munkavállaló a végzettségét, „csak meglegyen”. Az egyenértéküségben hívők elsődlegesen a felnőtt tanuló erős motiváltságát emelik ki értékként. A munkáltatók 80\%-a tartja ugyanolyan értékünek a felnőttkorban szerzett végzettségeket, $60 \%$-uk foglalkoztat is olyan munkavállalót, aki felnőttként ült vissza az iskolapadba.

\section{Merre tovább?}

Az, hogy megteremtsük a felnőttkori tanuláshoz való hozzáférést minden társadalmi csoport számára, egyrészt közös, társadalmi érdekünk. Másrészt meg kell adnunk az esélyt mindazok számára, akik felnőttként szeretnének továbbtanulni: az esélyt arra, hogy megváltoztathassák az életüket, kibontakoztathassák tehetségüket és személyiségüket.

Abban az esetben azonban, ha a képzési piramis alján rekedteket nem segítjük hozzá az önálló életvezetés képességéhez és a tanuláshoz való hozzáféréshez, az egész életen át tartó tanulás csak egyes társadalmi rétegek kiváltsága marad. Az utóbbi évtizedekben a mobilitási ráták alacsonyak, a reziliens tanulók aránya alacsony, az iskolarendszer változásaival kapcsolatban nincs valós társadalmi vita. A kérdőjelek számát növelik az utóbbi időben zajló oktatáspolitikai döntések, többek között a felsőoktatásba való belépés nehezítése, vagy a 6 éves korban történő kötelező beiskolázás, melyek további megfontolásokat igényelnek.

\section{Irodalom}

Bajusz K. (2014). Felnöttekhez felnövö iskola? Az iskolarendszerü felnőttoktatás aktuális társadalmi alapproblémái. Pécs: PTE FEEK.

Balázs É., Kocsis M. \& Vágó I. (szerk.) (2011). Jelentés a magyar közoktatásról 2010. Budapest: Oktatáskutató és Fejlesztő Intézet.

Council of the European Union (2003). Council Conclusions of 5 May 2003 on reference levels of European average performance in education and training (Benchmarks). Luxembourg: Publications Office of the EU.

https://op.europa.eu/en/publication-detail/-/publication/35b8e2a0-a9c3-4b9b-86549a9c74ef2603/language-en (Letöltés: 2011. 08. 28.)

Cserné Adermann G. (2000). Az önirányított tanulás. Tudásmenedzsment, 1(1), 4-10.

Csók C., Dusa Á. R., - Hrabéczy A., Novák I., Karászi Zs., Ludescher G., Markos V. \& Németh D. (2018). A hallgatói lemorzsolódás és háttértényezői egy kvalitatív kutatás tükrében. In Pusztai G. \& Szigeti F. (szerk.), Lemorzsolódás és perzisztencia a felsőoktatásban (pp. 38-62). Debrecen: Debreceni Egyetemi Kiadó.

Csoma Gy. (2000). Alapelvek az iskolai felnőttoktatás tananyagának korszerüsítéséhez. Új Pedagógiai Szemle, 50(11), 24-28.

Engler Á. (2014). A levelező tagozatos hallgatók elégedettsége és eredményessége. In Engler Á. (szerk.), Hallgatói metszetek: A felsőoktatás felnőtt tanulói (pp. 37-44). Debrecen: CHERDHungary.

Eurostat (n.d.*). Early leavers from education and training. https://ec.europa.eu/eurostat/statisticsexplained/index.php?title=Early_leavers_from_education_and_training (Letöltés: 2019. 12. 21.)

Eurostat (n.d.**). Statistics on young people neither in employment nor in education or training. https://ec.europa.eu/eurostat/statisticsexplained/index.php/Statistics_on_young_people_neither_in_employment_nor_in_education_ or_training (Letöltés: 2019. 12. 22.) 
Kerülő J. (2013). A felnőttkori tanulás kudarcainak lehetséges okai. Szakképzési Szemle, 29(3), 43-59. Kerülő J. (2018). „Menni vagy maradni?” - Lemorzsolódás a felsőoktatási intézményekben, okok és megoldási javaslatok. In Pusztai G. \& Szigeti F. (szerk.), Lemorzsolódás és perzisztencia a felsőoktatásban (pp. 170-189). Debrecen: Debreceni Egyetemi Kiadó.

KSH (Központi Statisztikai Hivatal) (2018). Statisztikai tükör: Oktatási adatok, 2018/2019 (elốzetes adatok). https://www.ksh.hu/docs/hun/xftp/idoszaki/oktat/okt1819.pdf (Letöltés: 2019. 12. 16.)

OECD (Organisation for Economic Co-operation and Development) (2019). CO3.5 Young people not in education or employment.

https://www.oecd.org/els/soc/CO_3_5_Young_people_not_in_education_or_employment.pdf (Letöltés: 2019. 12. 22.)

OFI (Oktatáskutató és Fejlesztő Intézet) (2009). A felnőttek iskolái II. 3.: Esélyteremtés a felnöttoktatásban. https://ofi.oh.gov.hu/3-eselyteremtes-felnottoktatasban (Letöltés: 2019. 11. 10.)

Varga A. (2018). A hazai oktatási integrációs tapasztalatok és a korai iskolaelhagyás megelőzése. In Fejes J. B. \& Szűcs N. (szerk.), Én vétkem: Helyzetkép az oktatási szegregációról (pp. 67-88). Szeged: Motiváció Oktatási Egyesület.

Zrinszky L. (1996). A felnőttképzés tudománya: Bevezetés az andragógiába. Budapest: Okker Oktatási Iroda. 